\title{
猫ひっかき病の治療経験
}

\author{
対馬いづはら病院整形外科 \\ 西口雅 彦・小田純 爾 \\ 矢野勝 已・鳥越雄史
}

\section{Two Cases of Cat Scratch Disease}

by

\author{
Masahiko Nishiguti, Junji Oda, Katumi Yano \\ and Takafumi Torigoshi
}

Department of Orthopaedic Surgery, Tusima Iduhara Hospital, Nagasaki, Japan

We treated two cases of Cat Scratch Disease (CSD), and investigated the following factors : (1) laboratory parameters, (2) imaging evaluation using MRI, (3) pathological examination, (4) bacterial cultures and (5) serological study.

Key words : Cat-scratch disease (猫ひっかき病), Rochalimaea henselae (ロカリメアヘンセラエ), Magnetic resonance imaging (MRI)

$$
\text { はじめに }
$$

我々は猫ひっかき病（以下 CSD と略す）の 2 症例 を経験し治療を行った。 MRIによる画像診断や Rochalimaea henselae (以下 R. henselae と略す) 血清抗体価の測定を行い，その診断的意義について検 討した.

\section{症例}

症例 $1 ： 9$ 歳, 女児.

主訴 : 右时関節痛

現病歴 : 平成 8 年 10 月 5 日頃より，右肘関節内上 顆に腫脹疼痛が出現し，10月 7 日当科を受診した. 生後 5 力月の子猫を飼っており， 2 力月前よりよく手 を引っかかれた。

既往歴 : 特記事項無し.

現症: 右肘関節内上顆に $2 \times 2 \mathrm{~cm}$ で弾性硬の圧痛 を伴ったリンパ節様の腫瘤を認めた。腋窩リンパ節は 触れなかった．また，手の引っかき傷は治㿉していた。
検査所見 : 白血球 $8630, \mathrm{CRP} 1+$

MRI：T 2 coronal 像で肘の内側上顆に腫瘤状の高 信号域がみられた（図 1 )。周囲の脂肪組織は網状を 呈しており, 皮下組織や脂肪組織の浮腫を反映してい た。化膿性リンパ節炎像である，Gd 造影 axial 像で は，腫瘤は比較的均一で周辺がやや強く造影された。

臨床経過：CSD を疑い， ミノマイシンによる治療 を開始した，局所の治療として，10月 28 日に生検を 行った. 生検時にわずかな白色の排膿がみられたが, 細菌培養は陰性であった，症状は術後軽快した，発症 後 6 力月後の R. henselae 血清抗体価は陰性であった.

組織学的所見 : 生検標本ではリンパ滤胞がよく発達 し，所々に壊死巣を囲んで類上皮細胞からなる肉芽腫 の形成が認められた。

症例 $2: 41$ 歳, 女性.

主訴：右肘関節痛

現病歷：平成 9 年 1 月 10 日頃より，右肘関節内上 顆に腫脹疼痛が出現し，1月 16 日当科を受診した。 生後 3 力月の子猫を飼っており, じゃれて遊ぶときに 


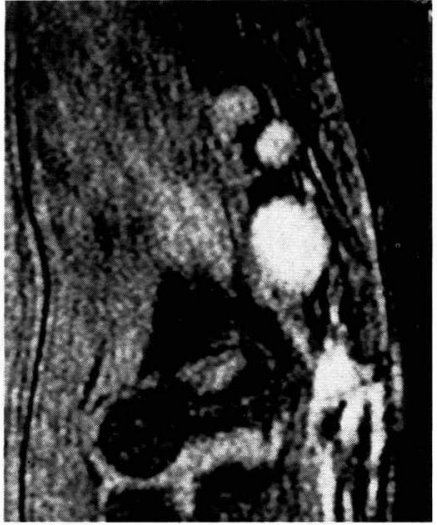

(a)

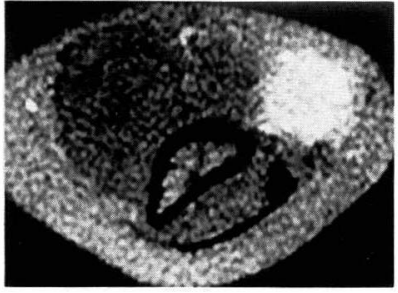

(b)

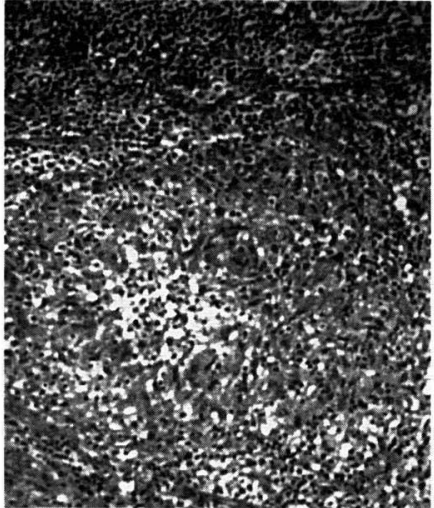

(c)

図 1 症例 1

(a) MRIT 2 像：肘の内側上顆に腫瘤状の集簇がみられる.

（b）MRI Gd 造影像：造影は均一で周辺がやや強い.

(c) 病理組織標本 : 肉芽腫の形成が認められる. $\mathrm{HE}, \times 100$.

\section{よく手を引っかかれた}

既往歴 : 特記事項無し.

現症 : 右时関節内上顆に発赤, 熱感を伴う㵒慢性の 腫脹があり, 圧痛を伴っていた，腋窩リンパ節は触れ なかった. 手の引っかき傷は治癒していた.

検査所見 : 白血球 $8820, \mathrm{CRP} 4+$

MRI：腫瘤は coronal 像で, T 1 で低信号, T 2 で高信号域を示し，リンパ節炎の所見を呈していた。 STIR 画像では, リンパ節の周囲の脂肪組織は網状で,
皮下組織や脂肪組織の強い浮腫を認めた（図 $2 \mathrm{a}, \mathrm{b}$ ). 臨床経過 : CSD を疑い, ミノマイシンによる治療 を開始した. 局所の腫脹が持続するので, 1 月 27 日 に切開, 排膿を行い, 組織学的診断を行った. 切開時 に多量の排膿がみられたが, 細菌培養は陰性であった。 症状は術後軽快し, 発症後 3 週後に R. henselae 血清 抗体価の測定を行ったが陰性であった.

組織学的所見 : 生検標本では多数の肉芽腫性病变が 形成され中心部には壊死が認められた。 また多発する

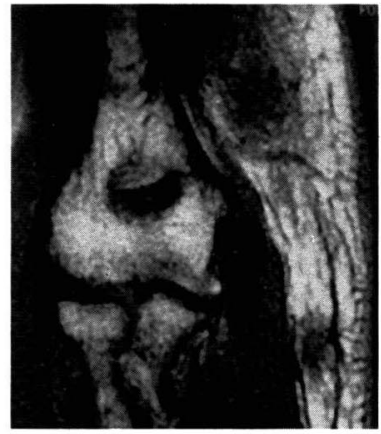

(a)

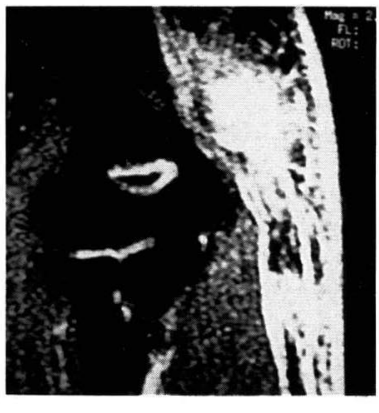

(b)

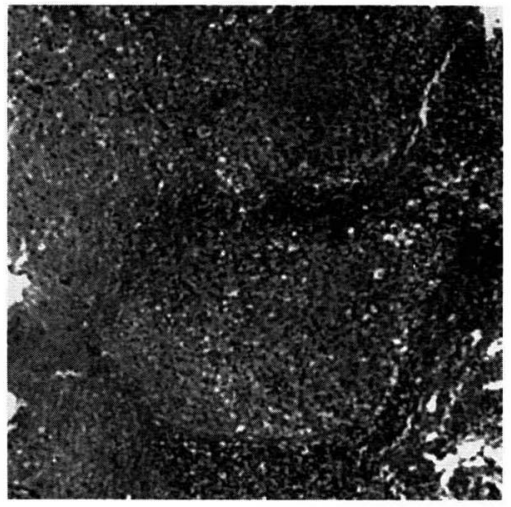

(c)

図 2 症例 2

(a) MRIT 1 像: 低信号でリンパ節炎像である.

(b) MRI STIR 像：リンパ節周囲の脂肪組織は網状を呈している.

(c) 病理組織標本：多発する小膿瘍を認める. HE, $\times 25$. 
小膿瘍が形成され好中球の浸潤と破砕物がみられた。 その辺縁では組織球も多数浸潤しており，壊死性リン パ節炎の所見であった（図２ｃ）.

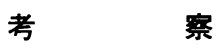

CSD は猫に引っかかれて起こる人畜共通感染症で, 最近の AIDS 研究の進歩により R. henselae が原因で あると言われている4).これまでの CSD の診断基準 には,（1）所属リンパ節の腫脹，（2）猫との接触歴,

（3）猫による受傷部位の確認，（4）特徴的なリンパ 節の病理組織学的所見，（5）CSD 皮内反応陽性，お よび（6）他疾患の除外の 6 項目があり，そのうち （1）と他の 5 項目中 4 項目を満たすことが診断確定 の条件となっている.

我々の症例は診断基準の（1）〜（4）は満たして いた. しかし（5）の皮内テストは，わが国では販売 されておらず入手は困難で, SRL 社 R. henselae に 対する, IgG と IgM の抗体価の測定がこれに代わる あのと考えられる ${ }^{2)}$. 現時点で CSD は R. henselae が原因と考えられているが，これ以外の菌の存在む報 告されており，病原体が 1 種のみではない可能性があ

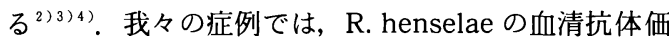
は陰性であったが，日本での陽性率は $50 \%$ との報 告 ${ }^{5)}$ があり，陰性だから CSD が否定されるものでは ない.

診断基準の他疾患の除外であるが，肘のリンパ節の 腫脹を来す疾患は, 一般的な化膿性リンパ節炎, 結核 性リンパ節炎, 真菌性リンパ節炎, 伝染性単核症, 野 鬼病, 白血病, 川崎病などが対象となる。これらと CSD の鑑別には猫との接触歴の問診が最も重要で, 我々の症例のように手の引っかき傷が治癒し, 診断困 難な場合もある.

画像診断で MRI は, 化膿性リンパ節炎像を呈し CSD に特異的ではない. しかし MRI で肘の化膿性リ
ンパ節炎像を呈し，猫との接触歴があれば， CSD が 最も疑われ，他の疾患との鑑別にも補助診断として有 用である ${ }^{1)}$.

CSD の治療は，免疫機能が正常であればその自然 経過は良好と言われている.しかし腫脹したリンパ節 は抗生剂の使用にあかかわらずあまり縮小せず遷延化 することが多いとの報告あある ${ }^{3)}$. 腫脹し膿の貯留し たリンパ節の切開排膿や摘出は, 外来手術で局麻下に 行え症状の軽快も早い, この際, 病理検査では, 微小 膿瘍を中心とした肉芽腫性リンパ節炎の所見が得られ る.

抗生剂はエリスロマイシン，テトラサイクリン系, ゲンタマイシンが有効との報告があり, 我々はミノマ イシンを使用し有効であった.

\section{ま と め}

1） CSD と診断した 2 例を報告した.

2 ） CSD の MR 画像は，化膿性リンパ節炎像であ り特異的ではないが，補助診断としては有用である.

3) R. henselae の血清抗体価の測定は，確定診断 として有用と言われているが，我々の症例では血清抗 体価は陰性であった。

\section{参 考 献}

1) Dong, P. R. et al. : Uucomplicatcd cat-scratch disease : Findings at $\mathrm{CT}, \mathrm{MR}$ imaging and radiography. Radiology, $195: 837-839,1995$.

2）森本雄次：PCR 法で診断した猫ひっかき病脳炎の 1 例. 日本小児科学会誌, 968-972, 1997.

3）山元紀子：ネコひっかき病の病原菌. 医学のあゆみ, $166: 561,1993$

4）山科元章 : 最近の猫ひっかき病. モダンメディア， 399 $-409,1995$.

5) Yoshida, H. et al. : Serological study of bartonella henselae in cat scratch disease in Japan. Microbiol. Immunol., $40: 671-673,1996$. 